\title{
The Ideological Shadow of Authoritarianism
}

\begin{abstract}
How do the labels left and right take on meaning in new democracies? Existing explanations point to the universality of the left-right scheme or, reversely, emphasize regionally dominant social cleavages. We propose an alternative legacy-focused theory based on two observations: dictatorships are not ideologically neutral, and are negatively evaluated by most citizens and elites after democratization. These premises lead us to expect that when the authoritarian regime is associated with the left (right), the citizens of a new democracy will display an anti-left (anti-right) bias in their left-right self-identification. We test this hypothesis across Latin American and European new democracies. We find significant bias, which in the case of new democracies following left-wing regimes is concealed due to inter-cohort heterogeneity. While older cohorts denote a positive bias, cohorts born after Stalin's era denote negative bias against the left. Consistent with our expectations, repression exacerbates this bias whereas indoctrination mitigates it. Finally, we look at how these biases apply to party preferences. The findings have important implications for understanding of authoritarian legacies and party system development in new democracies.
\end{abstract}

Keywords: left-right; anti-dictator bias; indoctrination; Post-Communism; Latin America 
Party competition is almost unthinkable without a spatial representation of both voters and parties along an ideological dimension (Brady 2011). Ideological classifications such as "left" and "right" help political parties to brand (Lupu 2013) and package (Zechmeister 2006) policy proposals and allow voters to cope with political issues in the context of imperfect information (Downs 1957); form political identities (Claassen, Tucker and Smith 2015; Devine 2015); and make political choices with limited awareness of the actual party policy positions (Adams, Ezrow and Somer-Topcu 2011). But whereas parties' long-run trajectories shape the symbolic meaning of these ideological labels in established democracies (Arian and Shamir 1983; Knutsen 1995), little is known about how these terms are understood in new democracies. Existing explanations focus either on the role of pre-existing social cleavages (Evans and Whitefield 1995; Kitschelt 1995, 1999; Tucker 2002; Whitefield 2002) or on factors that have emerged after the democratic transition: elite coordination (Zechmeister 2006); party system structuration (Harbers, de Vries and Steenbergen 2013); and trust in political institutions (Doyle 2011).

We take a different route. We draw on a distinguishing feature of these countries, namely the ideological connotations of their authoritarian past. The labels left and right are not a monopoly of democratic party competition; on the contrary, the left-right scheme has played a central role for the non-democratic regimes of the 20th century. Even though fascism-a leading ideology of the inter-war period-lost significance after World War II (WWII), the Cold War provided an unambiguous ideological context, leaving non-democratic regimes of the post-WWII period to orient themselves into pro- and anti-communist camps. These dynamics are not captured by the existing democratization literature, which has mainly focused on how the institutional features of non-democratic regimes conditioned their transition to democracy (e.g. Boix and Stokes 2003; Brownlee 2007; Gandhi 2008; Gandhi and Przeworski 2007; Geddes 1999; Hadenius and Teorell 2007; Przeworski 2000; Remmer 1985; Svolik 2012). Few studies have looked at the ideological connotations of non-democratic regimes (Gentile 2013; Levitsky and Way 2013; Linz 2000) and even fewer look at their legacies after democ- 
ratization (but see Pop-Eleches and Tucker 2017; Torcal and Mainwaring 2003). This lacuna is surprising given the resources dictators dedicate to controlling political language and disseminating the regime ideology. In this paper, we directly address this gap by examining whether and how the ideological connotations of autocracies colour the meaning of "left" and "right" in third wave democracies in Latin America, Eastern and Southern Europe. In doing so, we propose a new way of integrating the macro-level understanding of regime types and the micro-level understanding of the formation left-right (LR) self-identification.

We argue that, in new democracies, people's willingness to classify themselves as leftor right-wing is shaped by a general reluctance to identify with the ideological label associated with the past authoritarian regime. As a result, people in new democracies will place themselves further away from the end of left-right ideological spectrum associated with the prior regime than they would have otherwise. We call this tendency anti-dictator bias. If the past regime was left-wing as in the case of Eastern Europe, people will display an anti-left bias, and if the prior regime was right-wing as in the cases of Latin America and Southern Europe, people will display an anti-right bias.

We test our expectations with a harmonized dataset which covers 50 countries, 950 country-years, and two million individuals. We contrast both post-left-wing(LW) and postright-wing (RW) new democracies against the ideological benchmark provided by established democracies. We find evidence for anti-dictator bias in both post-RW and post-LW democracies, which seems to persist over time. We also try to shed some light on the mechanisms, by examining within-regime heterogeneity in the magnitude of the effects, conditional on two key characteristics of authoritarian regimes: repression and indoctrination. Our results highlight the importance of prior regime indoctrination for explaining the strength of these biases. Communist indoctrination in Eastern Europe had mitigating effects on anti-left biases among older generations. Finally, shifting our attention from ideological self-placement to party preferences, we find that in democracies following right-wing regimes, right-wing parties are additionally "penalized" by opposing voters. In Eastern Europe, we find that vot- 
ers dislike all opposing parties equally, and do not additionally penalize left-wing communist successor parties.

Our paper makes contributions in three areas. Firstly, we provide a parsimonious explanation for the cross-sectional variation in LR self-identification in Europe and Latin America today. With respect to Europe, which experienced both right and left-wing dictatorships, our explanation goes a long way in helping us understand cross-country variation in LR self-placement, as depicted in Figure 1, which shows the average LR self-placement for each country from the 2014 European Election Study. Secondly, we introduce ideological connotations of autocracies, as well as the modifying impact of regime characteristics, such as repression and indoctrination, as new variables for understanding the source of LR selfidentification and party competition in third-wave new democracies. Finally, we contribute to the growing understanding of the malleability of attachments to political "brands" (Lupu 2013) and the symbolic functions of ideological labels both as a short-cut for political choices and as a source of group identities. The paper makes a novel contribution to this extensive research by moving our focus beyond political parties as the primary objects of "left" and "right" labels to the consideration of entire political regimes.

Figure 1: An Ideological Map of Europe

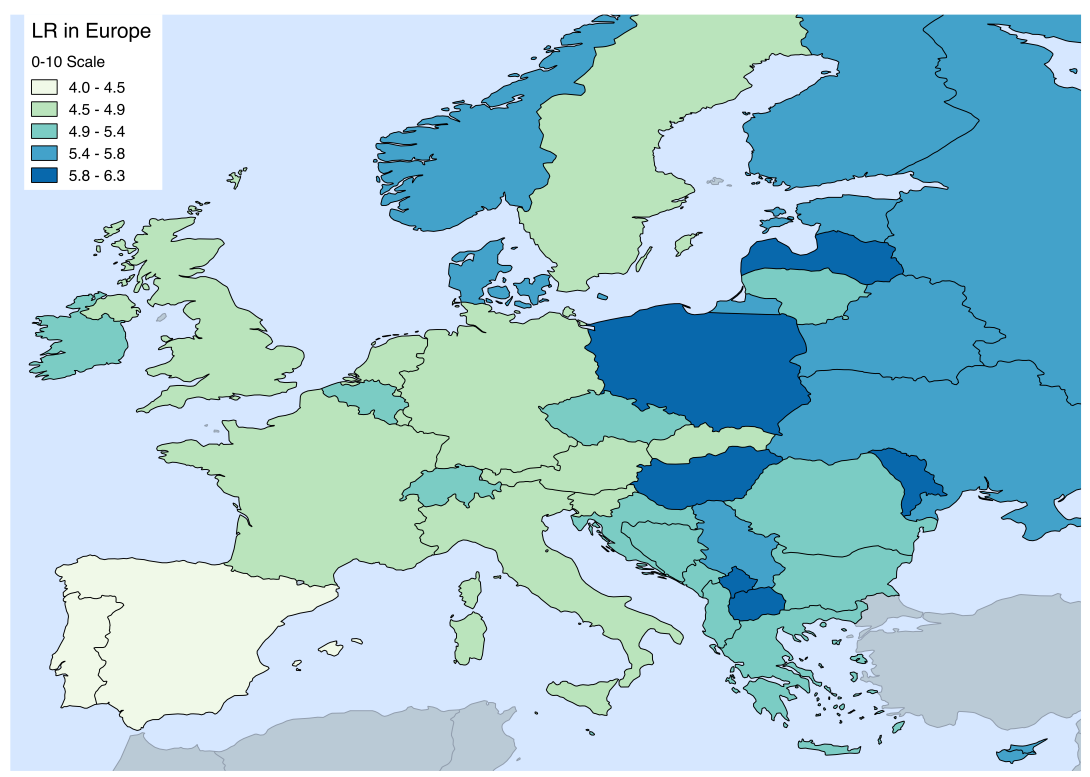

Source: European Election Study, 2014. 


\section{Anti-Dictator Bias}

The logic of anti-dictator bias rests on two principles. Firstly, autocracies are not ideologically neutral. Rather, they have either a left or right-wing association of which their own citizens, post-transition elites and the world at large are aware of. Not all citizens have to be aware of this link but a significant proportion need to for the argument to work. Secondly, on the whole, repressive regimes are assessed negatively after the transition to democracy. We do not preclude the possibility of anti-dictator bias extending beyond the labels to the content of labels e.g. the policies, ideologies, and associated parties, but within the scope of this paper, we concern ourselves with self-classifications using the ideological labels as the first step to understanding the roots and dynamics of anti-dictator bias.

We start with the link between autocracies and the ideological labels left and right. While the political left-right spectrum is a simple dyadic distinction, its power as a meaningful set of categories lies in its relativity - in other words, its ability to acquire new meanings based on changing historical and intellectual contexts (see Bobbio 1996). In the 20th century, the conflicts between liberal democracy and anti-liberalism (fascism, communism, corporatism) followed by the Cold War conflict between communism and capitalism helped to provide a grand context that facilitated the attachment of meaning to the dyadic categories of left and right.

The inevitable potential for an association between Communist regimes of Eastern Europe and the "left" end of the ideological spectrum can be taken as a given; Lenin (1920) himself used the term "left-wing" in association with the communist parties of Europe. The terms "left" and "right" were integral parts of the Marxist-Leninist political discourse, and average citizens would be well aware of how their "left-wing" regimes are in conflict with the "bourgeois right" and "reactionary rightist" regimes around the world (Robinson 1995). The

ruling communist parties - all members of the International-had full control of the state and used their resources to spread a Marxist-Leninist worldview throughout their societies, 
thus reinforcing a consistent political vocabulary(Meyer 1966).

The authoritarian regimes of Southern Europe and Latin America reflected a greater variety of motivating ideas, including nationalism, corporatism, fascism, populism, and later neoliberalism, thus making their classification on the left-right spectrum less straightforward than that of communist regimes (Freeden, Sargent and Stears 2013; Linz 2000). However, "anti-communism" provided a unifying right-wing identity for the diverse political factions that underpinned regimes in Southern Europe and Latin America. In the case of Francoist Spain, the theme of anti-communism endured to the regime's very end, culminating in the controversy surrounding the legalization of the Spanish Communist Party in 1977 (Linz and Stepan 1996: 96). Likewise, anti-communism was a central unifying, motivating, and legitimizing element for Salazar's Estado Novo in Portugal (Pinto and Rezola 2007) and for the Greek Junta (Kornetis 2013).

The centrality of anti-communism to regime 'mentalities' is particularly apparent in Cold War Latin America (Brands 2010, 241-42). Most of the Latin American regimes arose to prevent a pro-Soviet government from taking power or to fight left-wing insurgencies and were thus viewed as "right-wing" by virtue of playing an anti-communist role (see Appendix B for the ideological orientations of Latin American regimes). ${ }^{1}$ Brands 2010 goes even so far as to claim that the post-Cold War "destruction of the Left [...] robbed these governments of their reason for being" leading to the collapse of the Latin American authoritarian regimes. The strong association between military coups and the right is even apparent in regime classifications that combine the two elements creating a distinct category of "right-wing authoritarianism" (e.g. Alvarez et al. 1996).

1 Exceptions to the anti-communist trend in Latin America are not absent of course; Castro's Cuba or Nicaragua's Sandinista regime are examples of clearly leftist regimes that openly aligned with the Soviet Union. Several Latin American regimes (most notably Peru under General Juan Velasco Alvarado's rule (1968-1975)) primarily pursued populist and national reform policies thus making their right-wing associations less clear, but again in so far as they pursued a vigorous anti-communist policy these regimes were far more likely to be associated with the right (See Appendix B). 
If citizens are aware of the ideological orientation of the preceding regime, how will they evaluate the ideological label associated with old regime? We argue that there are at least three reasons as to why people in the post-transition period may not be willing to identify themselves with the prior regime's tainted brand. First, with the demise of an authoritarian regime, we expect the various mechanisms that generated compliance and support to cease functioning, thus leaving only the negative memories of the repressive aspects. Second, people who had kept their true preferences concealed through preference falsification (Kuran 1997; Lohmann 1994) now have incentives to openly display their dislike for past regime. Third, new social and political pressures can stigmatize support for the old regime's brand. These pressures include the new political discourse driven by political elites striving to bolster their legitimacy by emphasizing their break from the past, as well as the newly open statement of preferences by the segments of society that had not supported the regime before. We presume that this constellation of social and political forces can tip the balance far enough to render identifying with the old regime's brand and associated parties socially unacceptable and even trigger new forms of preference falsification whereby supporters of the old regime conceal their preferences in the new environment and are reluctant to self-identify with the brand of the old regime. In future research these individual mechanisms can be unpacked, but in this paper we focus on the overall effect that they have on left-right placement in the post-transition period.

But what about the legacies of genuine support for the old authoritarian regime? Of course, there is a distribution of preferences in any given society which means that some sections of the population did sincerely support the authoritarian regimes. Furthermore, authoritarian regimes had various means of building popular support for example through co-optation (Magaloni 2006), economic goods provision (Desai, Olofsgård and Yousef 2009), and propaganda (Chen and Xu 2017) among others. However after democratization, these mechanisms would cease to operate leading to a collapse in prior levels of support. One could still expect a lagged effect if specific authoritarian regimes were better at economic 
goods provision than the democratic governments that replaced them. But on the whole, we would still expect a considerable portion of the population to lean against the authoritarian regime.

Repression, on the other hand. while unifying feature of authoritarian regimes, may gain compliance (Kuran 1997) but is counter-productive in terms of gaining sincere popular support (Gerschewski 2018; Guriev and Treisman N.d.). Indeed the literature on authoritarian nostalgia suggests there has been and continues to be very little support for the purely repressive aspects of authoritarianism. Even in post-communist countries, where the phenomenon of "communist nostalgia" (Ekman and Linde 2005; Gherghina and Klymenko 2012), as well as critical attitudes towards democracy are well documented (Neundorf 2010; Pop-Eleches and Tucker 2017), it is clear few citizens yearn for the purely authoritarian aspects of the communist form of government (Mishler and Rose 1996; White 2010). Mishler and Rose (1996, p. 43) find that only a minority, about 3\%, endorsed all five "authoritarian" elements of a government type, and the most favoured "authoritarian" element was a technocratic management of the economy by economists. Overall, "communist nostalgia" appears to combine a yearning economic benefits of communism (White 2010) with a cultural identity as a communist citizen (Bartmanski 2011; Gherghina and Klymenko 2012). Likewise, in Latin America, where various accounts stress a latent cultural predisposition towards authoritarianism (see Tiano 1986, for a review), public opinion seems to be largely in favour of democracy both before the start (Geddes and Zaller 1989) and after the end of the authoritarian regime (Carlin and Singer 2011, 1509). Extensive survey evidence from Latin America has challenged the perception of an authoritarian culture, portraying a citizenry with pro-democratic values (Booth and Seligson 1984; Tiano 1986) and across at least eight countries, Latin Americans prefer elected democracy to an unelected strongman by a ratio of about five to one (Booth and Seligson 2009). Even allowing for variation in support for democracy and nostalgia across and within these countries, there are grounds for some degree of rejection of the authoritarian past. 
The tendency to disassociate from the ideological "brand" of the prior illiberal regime is clearly apparent in the behavior of party elites in new democracies. In the post-communist context, former Communist parties were largely discredited and shunned by other parties (Ishiyama 1995; Mahr and Nagle 1995). The instances of "success" are attributed to their ability to either re-brand themselves as social democratic parties (Grzymala-Busse 2002), obfuscate their links through 'ideological flexibility' (Pop-Eleches 2008), or rely on the historical weakness of the anti-communist opposition (Spirova 2008). To protect their anti-communist reputation, several ex-Communist parties have implemented economic liberalization despite their promises to the contrary in party manifestos (Tavits and Letki 2009) and some of them even initiated lustration policies (Letki 2002). Insofar as elite behavior carries some reflection of popular demand, we can infer that in post-communist countries, the communist brand was penalised to some extent by voters.

In Latin America, political elites have shown a reluctance to be labelled "right-wing." Studies of Brazilian political elites have recorded a long-term tendency towards what has been known as the direita envergohada ('ashamed right'): politicians place themselves to the left of their actual positions and they refuse to label themselves as "right-wing" (Pierucci 1987; Power and Zucco Jr 2009). The reluctance of political elites to label themselves rightwing may explain the high level of confusion in LR self-placement among latent 'rightists' in the Brazilian electorate (Ames and Smith 2010). By the same token, PSR, the main rightwing party in Portugal, has avoided using a name that would link it to any common party family of the right. Rather it opted to call itself 'social democratic.' Some studies have argued that Spain and Portugal have been rendered immune to far-right populist parties despite the recent grave political and financial crises precisely because of their experience of four decades of right-wing authoritarianism (González-Enríquez 2017). Likewise, the Greek socialist party has traditionally exploited memories of the turbulent and polarized period that led to the 1967 right-wing military coup in its campaign strategy (Dinas 2017).

To conclude, for anti-dictator bias to appear in the post-democratization period it is 
enough that a non-trivial proportion of the population associated the old regime with either the left or the right and did not sincerely support the old regime - and this group is likely to be present as authoritarian regimes do not need support from everyone to survive (Kuran 1997). At the very least we would expect a new and cross-cutting cleavage between old and new regime supporters in the new party system (Torcal and Mainwaring 2003; Tucker 2006). Combining the two parts of our argumentation leads us to our main hypothesis:

$H_{1}$ :In post-authoritarian regimes, individuals will have a bias against the ideological label of the prior illiberal regime.

This hypothesis can be further decomposed, according to the ideological label of the illiberal regime:

$H_{1 A}$ : If a country had a left-wing illiberal regime, we expect an anti-left bias under democracy. $H_{1 B}$ : If a country had a right-wing illiberal regime, we expect anti-right bias under democracy.

Apart from testing these hypotheses, we try to validate our argument by exploring sources of variation in the resulting degree of anti-dictator bias. We propose that the two main characteristics of autocracies will underlie this variation: the intensity of the repression and indoctrination used by the old regime. A particularly brutal and memorable record of repression that violates basic human rights, which are seen as integral to democracy, is likely to fuel the regime's bad reputation. Hard repression (Levitsky and Way 2010) is more likely to undermine legitimacy than subtler forms (Escribà-Folch 2013), increase opposition (Davenport 2007), and the demand for transitional justice after democratization (O'Donnell and Schmitter 2013). Thus repression is likely to increase the proportion of people who lack sincere support for the old regime and fuel the anti-dictator political discourse. Indoctrination by the old regime, on the other hand, should mitigate anti-dictator bias. 
Successful inculcation of the population with regime's guiding idea (Brandenberger 2014) helps people rationalize the need for repression (Adler 2012) and creates a religious-like devotion to the regime (Gentile 2013). Indoctrination has particularly durable effects due to its reliance on education (Alesina and Reich 2013) targeted at the impressionable young as well as due to the creation of new social identities (Fitzpatrick and Ludtke 2009). We thus expect the legacies of indoctrination and repression to modify the overall level of anti-dictator bias in countervailing directions.

\section{Data and Research Design}

We understand anti-dictator bias as the tendency of people to place themselves further away from either end of the left-right continuum than they would without negative associations with the old regime's ideological side. In other words, the ideology of the old regime, in the sense of an association with the ideological label "left" or "right", serves as the treatment (Right for right-wing and Left for left-wing), which determines peoples' self-placement on the left-right scale: following a right-wing regime, people will place themselves to the left, and following a left-wing regime, to right. However, in order to test for the presence of antidictator bias, we need a benchmark against which to judge what is more "left" or "right."

To address this challenge, we use established democracies as the comparison group. We define established democracies as countries that had uninterrupted democratic rule since WWII. We assume that in these countries there exists no anti-dictator bias by the time our first surveys are available (early 1970s). We do not assume that established democracies do not display left or right-wing tendencies but rather that the ideological "brand" of the pre-democratic regime has no effect. All these first-wave democracies democratized slowly, reaching full democracy well before WWII (Huntington 1993), and while some experienced a brief authoritarian interlude (i.e. Nazi occupation), it was sufficiently short and far in the 
past to have a neutral effect on LR self-placement. ${ }^{2}$

Using established democracies as the benchmark has two further advantages. Firstly, established democracies can be used as the point of comparison for both left and right-wing regime types facilitating a comparison between the two latter groups. Secondly, the use of established democracies as the comparison group accounts for period effects such as general swings in public opinion that affect people cross-nationally.

We pool several cross-national surveys that include a left-right self-placement item: the World Values Survey, the European Social Survey, the European Elections Studies, the Latinobarometer, the Eurobarometer and the Central and Eastern European Barometer surveys. In total, our surveys cover 50 countries in the period from 1970 to 2012. This results into 950 country-years and about two million individuals. ${ }^{3}$

The scatterplots in Figure 2 summarize the data by showing the average LR self-placement in each survey for the three groups of countries: new democracies following left and rightwing regimes and established democracies. Each dot represents a country-year survey and their size is proportional to the survey's effective sample (excluding observations with missing $L R$ values). Local smoothing functions summarize the overtime trajectory suggesting that people in new democracies which followed right-wing regimes are the most left-wingmore left-wing than people in post-Communist countries and established democracies. Also, people in both groups of new democracies show trends towards more right-wing placements as time passes since the transitions, but this trend stabilizes in post-right-wing democracies.

However, Figure 2 also illustrates the difficulties arising from direct comparisons between post-LW and post-RW new democracies. Since the timing of the transition varies between countries, all surveys from post-authoritarian countries (first panel of the graph) are sorted according to the year of fieldwork relative to the year of regime change. This variation makes a direct comparison of the two curves for the new democracies problematic - in doing

2 We relax this assumption in some analyses, as explained in the next section.

3 Details of the years and countries covered in Appendix A of the Online Appendix (OA)). 


\section{Figure 2: Descriptive Statistics}
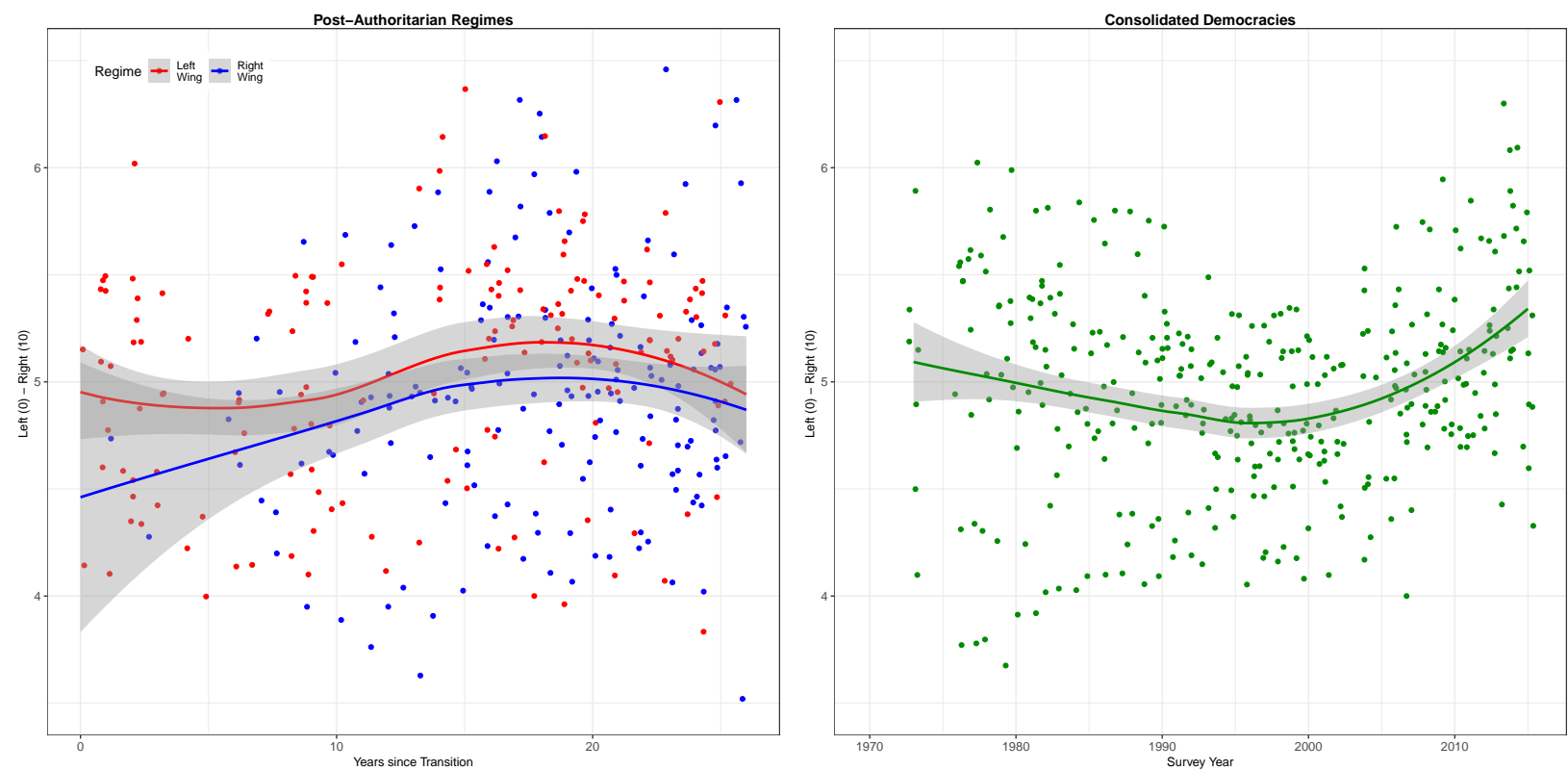

Note: The first panel shows the surveys available in post-authoritarian regimes, distinguishing between postLW and post-RW democracies with red and blue respectively. The right panel presents the consolidated democracies. Each point denotes the average LR self-placement. The horizontal axis denotes the years since transition for the post-authoritarian regimes and the actual survey year for the consolidated democracies. The curves denote local regression curves $(\operatorname{span}=1)$.

so, period effects would be ignored. This problem illustrates why established democracies are needed as the common point of comparison.

To further clarify how we construct this comparison between the "treated" new democracies and untreated established democracies, we present the main equation used in our analysis. Assuming that the authoritarian regime of a country $j$ ends at year $c$, the resulting equation takes the following form:

$$
L R_{i j \tilde{t}}=\alpha+\beta \text { Left }_{j}+\gamma \text { Right }_{j}+\delta \tilde{T}_{\tilde{t}}+\text { Survey }_{k}+u_{i j \tilde{t}}
$$

where $\tilde{t}=t-c$ denotes the number of years elapsed since the old regime ended, $i$ indexes individuals, $\tilde{T}$ denotes a time trend, centered with respect to the transition year, thus $\tilde{T}=$ $\{0, \ldots, W\}$, and $L_{e} f t_{j}$ and $R i g h t_{j}$ switch on for left and right-wing dictatorships respectively (with established democracies as reference category). We also include a dummy for each type 
of study (EES, ESS, WVS, Latinobarometer, Eurobarometer, CEE barometer, thus $k=5$ ). Centering time with respect to the year of regime-end means that the effect of Right and Left is evaluated at year $c=0$, i.e. right after the end of the authoritarian rule.

The problem is we cannot readily estimate LR self-placement at year $\tilde{T}$ for established democracies, because $c$ does not exist for them; we need to infer it. For example, for a country such as Hungary, which democratized in 1990, a survey in year 2000 would provide responses ten years after the transition. For the control group we would like to take people from established democracies from the same period i.e. those surveyed in 2000. Indeed, when using established democracies against left-wing regimes, we assume $c=1990$, which corresponds closely with regime-change year in most of these countries. To keep the analysis compact, we use the same $c$ for post-RW democracies. Doing so allows us to employ the same equation for both sets of analyses. Yet, acknowledging that many RW regimes democratized before 1990 (e.g. Argentina 1983; El Salvador 1985), we replicate the analysis only for the right, using different c's: 1975, 1980 and 1985.

We extend this estimation in various ways. First, we add a series of time polynomials to better capture the effect of time since regime end. Second, we add various pre-treatment covariates: GDP per capita, infant mortality, the rate of urban population, education inequality, and colonial status. ${ }^{4}$ For the right-wing countries we use the average between 1990-1920. This information is not always available for some of the left-wing regimes and thus we take the average for the period 1925-1935. All data come from the Varieties of Democracy (V-Dem) dataset (Coppedge et al. 2017). Finally, in some specifications we also include individual-level controls gender (age with two polynomials, education and level of religiosity, fully factorized) and post-treatment country characteristics: unemployment, inflation, growth and inequality during the time of the survey (International Monetary Fund:

${ }^{4}$ V-Dem variable details and names: GDP per capita, logged, base 10 (e_migdppcln); Infant mortality rate (e_peinfmor); Education inequality measure (v2peedueq) based on an expert evaluation of extent high quality basic education guaranteed to all; Colonial status (v2svdomaut) measure based on an expert evaluation of extent domestic policies autonomous from other states. 
World Economic Outlook Database 2018; Solt 2016).

Moreover, we explore the presence of moderator effects, by looking at the role of time and cohorts. Taking into consideration the full time span after democratic democratization helps us to gauge the longevity of anti-dictator bias. We do this by interacting $\tilde{T}_{\tilde{t}}$ with both Left and Right:

$$
\begin{array}{r}
L R_{i j \tilde{t}}=\alpha+\beta_{1} \text { Left }_{j}+\gamma_{1} \text { Right }_{j}+\delta \tilde{T}_{\tilde{t}}+\beta_{2} \text { Left }_{j} \times \tilde{T}_{\tilde{t}}+\gamma_{2} \text { Right }_{j} \times \tilde{T}_{\tilde{t}} \\
+ \text { Survey }_{k}+v_{i j \tilde{t}}
\end{array}
$$

where $\beta_{1}$ and $\beta_{2} \times \tilde{T}_{\tilde{t}}$ provide the average difference in LR self-placement between left-wing dictatorships and old democracies from year zero up to year $\tilde{W}$. Using $\gamma_{1}$ and $\gamma_{2} \times \tilde{T}_{\tilde{t}}$, we take the equivalent information but for the right. Similar to the previous analysis, we use various specifications, which include pre- and post-treatment covariates as well as higher time polynomials.

Next, we look into cohort-specific effects. The rationale behind this exercise is that we should not expect all respondents to have been equally affected by the ideological label of the authoritarian past. At the very least we expect some difference between people who experienced the regime and people who did not. We extend equation (1), to account for between-cohort differences. To identify cohort effects against period and ageing effects, we apply an augmented difference-in-differences design, as suggested by (Dinas and Stoker 2014). Instead of comparing different cohorts of the same group of countries, we compare same cohorts of different group of countries: post-LW democracies, and post-RW democracies against established democracies. We also include four time polynomials, interacted with both Left and Right. This specification allows us to identify cohort effects without having to assume that ageing or period effects are zero. Rather, we simply assume that ageing effects in LR self-placement operate in the same way in both new and established democracies. Building on this idea, we can estimate cohort effects for each cohort in the analysis, thus 
allowing the data to reveal any between-cohort differences. No artificial groups of cohorts are used:

$$
\begin{gathered}
L R_{i j \tilde{t}}=\alpha+\beta_{1} \text { Left }_{j}+\gamma_{1} \text { Right }_{j}+\delta_{\xi} \tilde{T}_{\tilde{t}}^{\xi}+\delta_{R \xi} \tilde{T}_{\tilde{t}}^{\xi} \times \text { Right }+\delta_{L \xi} \tilde{T}_{\tilde{t}}^{\xi} \times \text { Left } \\
+\lambda_{m} \text { Cohort }_{m}+\beta_{m} \text { Cohort }_{m} \times \text { Left }+\gamma_{m} \text { Cohort }_{m} \times \text { Right }+ \text { Survey }_{k}+e_{i j \tilde{t}}
\end{gathered}
$$

where $c=1990, \xi=\{1,2,3,4\}$, and $m=\{1931, \ldots, 1993$, post -1993$\}$. Post-1993 includes all respondents born after 1993. Since we only include respondents born later than 1929, $\beta_{1}$ and $\gamma_{1}$ estimate the difference in LR self-placement between right, left and established democracies for everyone born in 1930. $\beta_{1}+\beta_{m}$ and $\gamma_{1}+\gamma_{m}$ estimate the same difference in LR self-placement for each next cohort, born between 1931 and up to post-1993, comparing the post-LW and post-RW regimes respectively against the established democracies. As a last step in this set of analyses, we combine time and cohort effects by looking at how cohort effects evolve along the process of party system consolidation. We combine equations 2 and 3 into a single encompassing model that allows for cohort-effects to vary over time.

Finally, we try to tap into two possible modifiers of anti-dictator bias, namely the role of repression and indoctrination. We explore variation in both of these components within each regime. Making use of the $\mathrm{V}$-Dem indicators, we employ a ready measure of repression and construct an index of indoctrination. With regards to the former we use the Civil Liberties Scale (v2x_civlib), which is the broadest measure, covering the threat of physical violence as well as freedom of expression. We take the average level of repression over the duration of each regime as an indicator of the overall level of repression used by each regime.

To measure indoctrination we have created an index using individual V-Dem indicators to capture the key elements/tools of indoctrination: (1) the monopolization of the public discourse and exclusion of alternative views, (2) the presence of a clear ideology, (3) the control and exclusion of organizations that could provide alternative views, and (4) the presence of regime-controlled institutions that have mass penetration of society such as mass 
membership organizations and a developed education system (See Appendix C of the Online Appendix for full details). ${ }^{5}$ As with repression, we take the average level of indoctrination over the duration of each regime.

\section{Results}

Table 1 shows the results from Equation 1. The first row denotes new democracies following right-wing regimes whereas the second row denotes democracies following left-wing regimes, that is post-communist Eastern Europe and Nicaragua. Respondents from established democracies are the reference category. Going across the columns, we gradually increase the number of various controls included in the model: firstly survey-fixed effects and a time trend (1), then we add "pre-treatment" controls (2), followed by "post-treatment" controls such as individual level demographics and post-transition economic conditions.

Looking at the right-wing dictatorships, we find that across all columns of Table 1 respondents are on average more left-wing than respondents of both left-wing dictatorships and those of established democracies. The effect amounts to an approximately 0.3 increase in a 0 to 10 scale. Given that the average LR self-placement in established democracies during this period is 4.81 , the effect amounts to a $6 \%$ decline in LR self-placement. Although this seems a modest effect, it is equivalent to the difference between secondary and tertiary education in an analysis using survey data from Germany (Barberá et al. 2017) and is approximately half of the effect of having a parent leaning to the left (Rico and Jennings 2016). The effect seems robust across all model specifications.

To what extent are these results driven by over-time heterogeneity? We address this question by estimating Equation 2. The results are summarized in Figure 3. We find an interesting temporal trend. ${ }^{6}$ Although there seems to be an anti-dictator bias throughout

${ }^{5}$ In the OA we explain the rationale behind the construction of the scale and we assess the sensitivity of our main results to alternative measurement assumptions.

${ }^{6}$ Detailed results are shown in Table D.1 of the Online Appendix. 
Table 1: Main Results

\begin{tabular}{lcccc}
\hline \hline & $(1)$ & $(2)$ & $(3)$ & $(4)$ \\
\hline Right & $-0.217^{* * *}$ & $-0.264^{* * *}$ & $-0.212^{* *}$ & $-0.320^{* * *}$ \\
& $(0.063)$ & $(0.079)$ & $(0.104)$ & $(0.114)$ \\
Left & -0.044 & 0.079 & 0.003 & 0.0192 \\
& $(0.056)$ & $(0.099)$ & $(0.119)$ & $(0.118)$ \\
\hline Survey-FE & $\checkmark$ & $\checkmark$ & $\checkmark$ & $\checkmark$ \\
Time Trend & $\checkmark$ & $\checkmark$ & $\checkmark$ & $\checkmark$ \\
Pre-WWII & & $\checkmark$ & $\checkmark$ & $\checkmark$ \\
controls & & & & \\
Individual-level & & & $\checkmark$ & $\checkmark$ \\
controls & & & & \\
Post-Transition & & & & $\checkmark$ \\
Controls & & & & \\
$n$ & 1168471 & 947214 & 511444 & 471039 \\
$n$ of clusters & 787 & 602 & 471 & 431 \\
\hline \hline
\end{tabular}

Entries are OLS coefficients, with robust standard errors, clustered at the country-year level, in parentheses. $c$ is defined as 1990 for established democracies, which are employed as the baseline category.

${ }^{*} p<0.1,{ }^{* *} p<0.05,{ }^{* * *} p<0.01$

the first two decades after the authoritarian rule, this bias decreases with time as the new democracies consolidate. At least two explanations can be given for this pattern: learning and generational replacement. Democratic learning implies that the accumulated experience of the new political regime and its actors will challenge, qualify or contradict the ideological biases related to the previous regime. Generational replacement implies that the new cohorts replacing the older ones are less distinct from those in established democracies. These two explanations can of course work in parallel and reinforce one another.

Before moving to the post-LW democracies, it is important to assess the robustness of these results. To do so, we perform a series of tests. First, we add up to four time polynomials in Equation 1, but all results remain substantively identical (Table D.2 of the Online Appendix). Second, to ensure that we are not capitalizing on a potential right-wing shift in industrialized democracies after the end of the cold war, we employ alternative starting years for these countries: 1975, 1980, and 1985. The results are very similar to those obtained when using 1990 as the starting point for old democracies (Tables D.3-D.5, Figures D1.-D.3 
in Online Appendix). Third, the results remain robust when we exclude Austria, Italy and Germany from the group of control countries or code them as right-wing regimes (Figures D.4 and D.5). Fourth, we implement the analysis at the country $\times$ year level, averaging LR self-placements for each survey year in each country. The results are substantively identical to those presented here (Table D.6, Figure D.6 in the Online Appendix). Fifth, we repeat the analysis using only a binary indicator denoting right-wing respondents (coded as those above five in the (0-10) LR scale). ${ }^{7}$ The results, shown in the Online Appendix (Tables D.7-D.10, Figure D.7), remain very similar to those presented here. Sixth, focusing on the over-time trajectory of the bias, we examine whether we still observe convergence when allowing for a very flexible specification of time. We use year dummies, which we interact with the indicators of right-wing regimes. The results are shown in the Online Appendix (Figure D.8) and largely confirm the pattern of convergence found in the main analysis. Seventh, to enhance the cultural and historical similarity between right-wing dictatorships and the control group used as the benchmark, we use as a comparison unit a Latin America country, which did not encounter a right-wing military regime, namely Costa Rica. We employ the same $c$ points as when using established democracies as control group. Tables D.11 and D.12 present the average effects, whereas Figure D.9 denotes the over-time trajectory. The results confirm the patterns found here. Finally, to assess the sensitivity of the results to the choice of the benchmark group, we sequentially exclude one country from the control group. All results, shown in the Online Appendix (Tables D.13-D.20, Figures D.10-D.17), are substantively identical to those presented here.

We now turn to post-LW new democracies. We see that people in post-communist Eastern Europe on the whole are not significantly different in their LR self-placement compared to established democracies. The magnitude of the effects is five to ten times smaller than

7 The rationale for this test is that although a binary indicator might lose information, it can be more readily comparable across countries. Although differences may exist about fine-grained scales, people, on the whole, tend to agree that values above five is right-wing and below five, left-wing (Bølstad and Dinas 2017). 
Figure 3: Over-time trajectory of LR self-placement, comparing left- and rightwing dictatorships with established democracies.
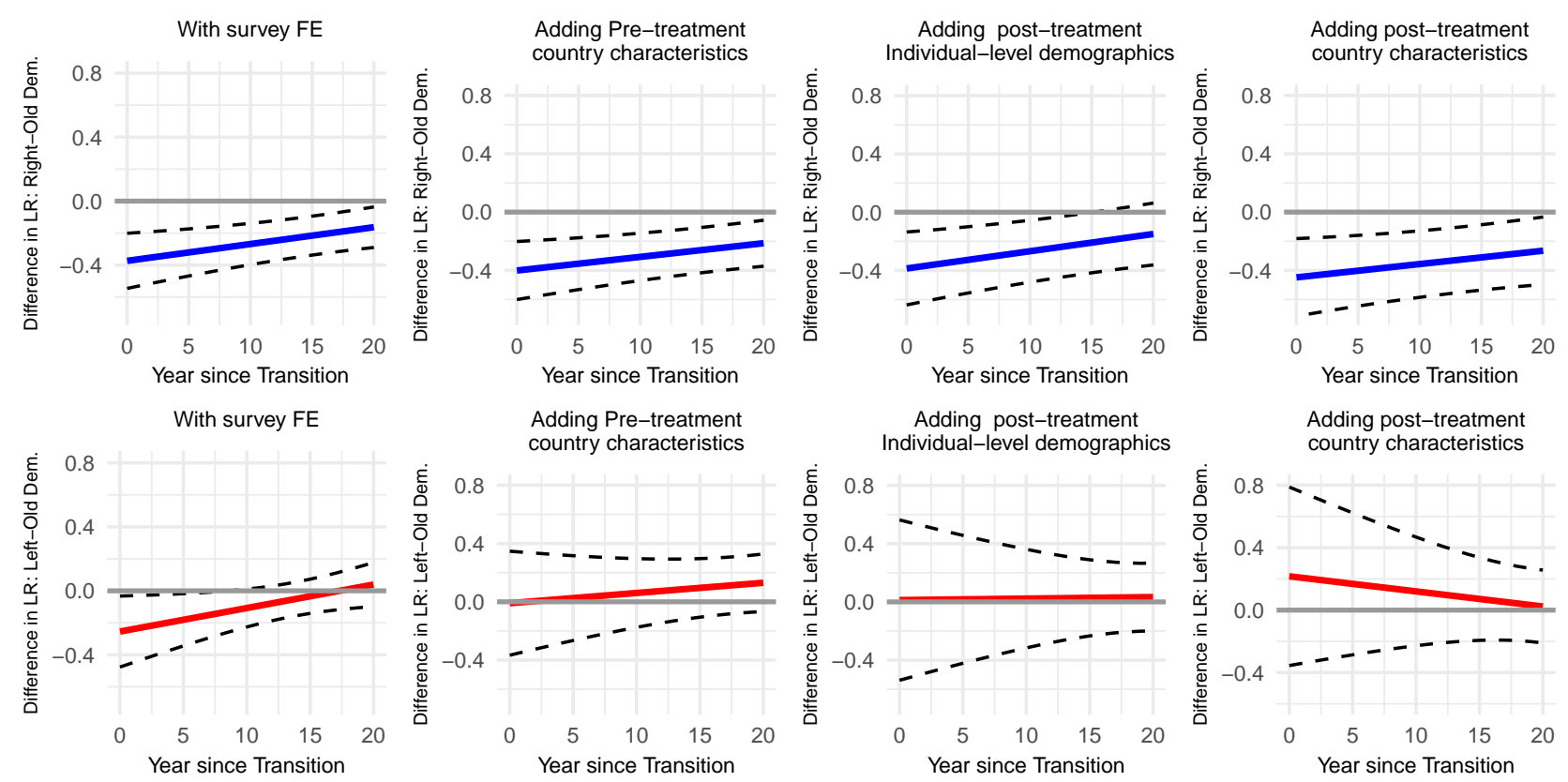

Note: The blue lines denote the difference in LR placement between right-wing dictatorships and established democracies, while the dashed curves denote the $95 \%$ confidence intervals.

for post-RW democracies. It never achieves conventional levels of statistical significance and changes sign across specifications. When decomposing these effects over time, the findings remain ambiguous, as shown in Figure 3: in the first model people in Eastern Europe appear to be slightly more left-wing in the early transition period, but this effect quickly ceases to be statistically significant at the $5 \%$ level. Moreover, the pattern seems to change remarkably when post-treatment controls are included. Yet, differences remain non-significant throughout the analysis. ${ }^{8}$

${ }^{8}$ Despite the lack of significant and coherent differences between post-LW new democracies and established democracies, for completeness we implement all robustness tests we also implemented for the right (with the exception of Costa Rica). The results are shown in the Online Appendix, together with the results for post-RW new democracies. 


\section{No anti-dictator bias for the Left?}

So why is there clear evidence of anti-dictator bias (anti-right) in democracies following rightwing regimes but no discernible anti-dictator bias following left-wing communist regimes? We believe this difference is the result of Communist regimes being better at indoctrination than military regimes, and having successfully built lasting left-wing identities and preferences among their citizens. Communist regimes were more efficient at indoctrination for two reasons: they possessed a highly developed ideology rather than vague 'mentality' (Linz 2000) and an institutional structure that facilitated indoctrination.

Firstly, a developed ideology is easier to teach in mass education (Kenez 1985; Zajda 1988), it enables psychological and emotional identification with the regime, and is more appealing to intellectuals and the youth (Arendt 1973; Fitzpatrick and Ludtke 2009). Furthermore, Communist ideology was underpinned by a body of widely-accessible MarxistLeninist literature further facilitating consistency in teaching and policy-making. Military regimes, on the other hand, mainly justified their existence based on some external threat, as manifested by the declarations of regime principles issued after coups (examples include Papadopoulos's "Our Creed" in Greece or Pinochet's "Declaration of Principles" in Chile). A vague guiding aim had the advantage of blunting cleavages in the coalition backing the regime, but at the same time it severely limited the capacity to socialize the masses into supporting the regime.

Secondly, the presence of a single mass-membership party not only increased regime longevity (Geddes 1999; Smith 2005), but also maximized penetration and control of society by fostering unified group identity across all state, social and economic institutions (e.g. schools, universities, youth groups, and workplaces). Military-authoritarian regimes, on other hand, were limited by the military-civilian divide: even if officer training could serve as means of indoctrination (as in the case of the teaching of "New Professionalism" in Brazilian military academies), it operated only within the military sphere. Also right-wing 
regimes relied on the Catholic Church to assist with education and indoctrination in the early 20th century. However, following the Second Vatican Council in 1958, the Church officially supported the cause of democracy curtailing any unequivocal support of authoritarian regimes (Philpott 2004). ${ }^{9}$

There is no doubt that long-lived illiberal regimes experienced fluctuations in levels of indoctrination and repression (Pop-Eleches and Tucker 2013, 2014). However, we can expect communist regimes to be on average more effective at indoctrination than right-wing regimes. Also it has already been shown that increased exposure to communist indoctrination significantly reinforces pro-left self-placement (Pop-Eleches and Tucker 2017).

Figure 4: Repression and Indoctrination across different types of regimes.
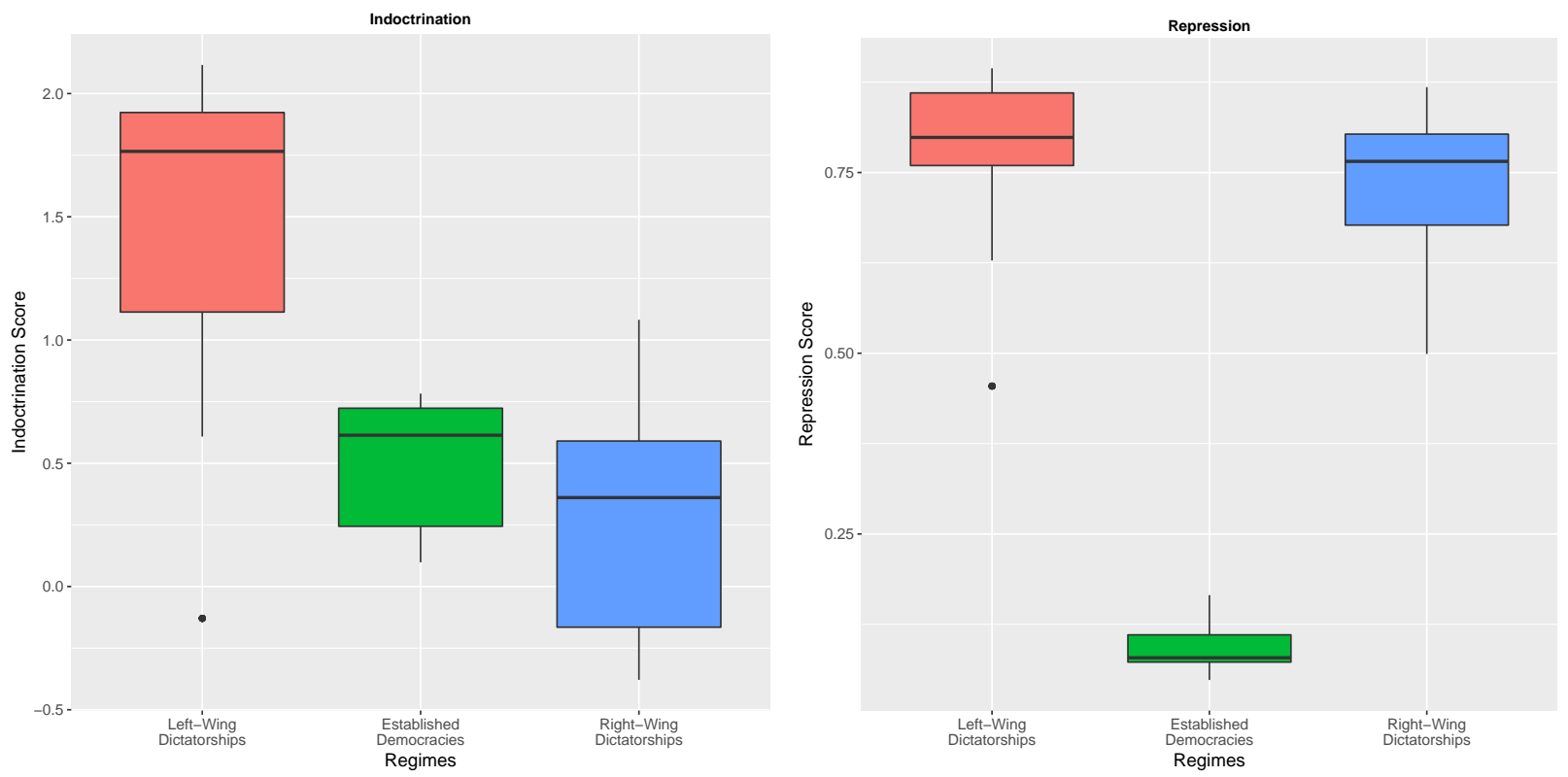

Note: Each boxplot summarizes the distribution of indoctrination (Panel A) and repression (Panel B) across the three types of regimes. The Online Appendix explains in detail how both measures have been constructed.

To test this argument, we first try to gauge the level of repression and indoctrination across different regimes. Figure 4 shows that levels of indoctrination among communist

${ }^{9}$ In a few exceptions the Church took a neutral position, the most notable case being the unusually emasculated Church in Argentina that was dependent on state funding (Gill 1998; Klaiber 2009). 
regimes were higher than for right-wing regimes and established democracies (the latter two being statistically indistinguishable). This pattern suggests that the moderating effects of indoctrination would have been felt much more strongly among left-wing regimes, thus explaining why in these countries, among the older cohorts, we see positive (pro-left) rather than negative bias (anti-left) towards the ideological label of the old regime. Of course, this reasoning assumes that indoctrination and repression are not perfectly related. The second panel of Figure 4 confirms this assumption: while the levels of repression between left and right-wing regimes are practically indistinguishable, the levels of indoctrination are much higher for left-wing than right-wing regimes.

Although suggestive and based on imperfect measures, the pattern shown in Figure 4 indicates that there is indeed some variation in the intentions of the two types of regimes. The next question is whether this difference in indoctrination intensity leaves any imprint on attitudes. Although we cannot provide direct evidence about the link between past indoctrination and contemporary LR self-placement, we can offer indirect evidence, by looking at between-cohort heterogeneity. If indoctrination matters, it should matter for those who directly experienced it because indoctrination ends or changes direction after the end of the authoritarian regime. We should thus find differences between cohorts that experienced the regime directly and those that did not. 
Figure 5: Between-cohort differences.

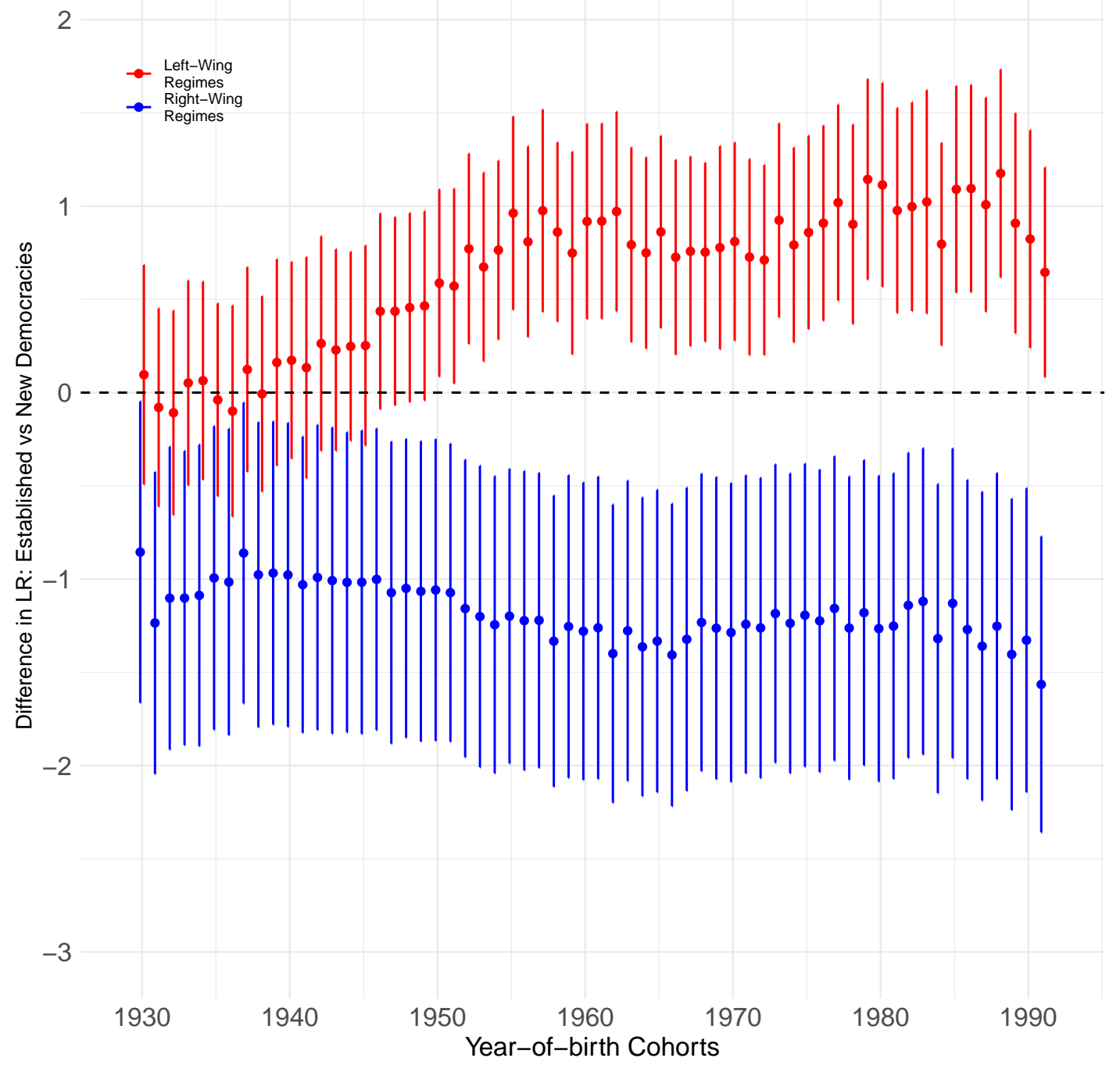

Note: Dots represent the difference between left-wing and established democracies for each birth cohort, with the vertical spikes denoting the $95 \%$ confidence intervals.

To see whether this is the case, we estimate equation 3. The results are shown in Figure 5. In this Figure we show predicted difference in LR self-placement between cohorts in new democracies and established democracies while controlling for the various pre-treatment effects. We see that in new democracies following right-wing regimes, there is no discernible between cohort heterogeneity and all cohorts tend to be more left-wing. However, if we look at post-left-wing new democracies, we find clear cohort heterogeneity that remains constant. 
People born between 1930 and 1950, and who not only experienced the most intense periods of communist indoctrination but were also exposed to it for the longest period, are more left-wing than younger cohorts - in other words the experience of indoctrination has pulled these cohorts to the left. The younger cohorts born from 1950 onwards that missed the earlier phases of intense communist indoctrination are right-wing as expected. Thus we can see that the absence of overall anti-dictator bias is driven by the more pro-left older cohorts out balancing out the younger right-wing cohorts. Thus for cohorts entering political life after the Stalinist era, we find significant anti-left bias.

Next, we combine the time and cohort effects to look at how cohorts behave over time. The results are summarized in Figure 6. Again we see an absence of cohort heterogeneity for most of the time in post-right-wing democracies (the initial heterogeneity fades quickly). But what we do see is that all cohorts become less left-wing over time thus displaying gradual convergence. But in post-left-wing new democracies we see that the cohort heterogeneity remains present over the two decades since democratization. The old cohorts who were exposed to communist indoctrination remain pro-left whereas the younger cohorts are all right-wing.

\section{A Direct Look at Repression and Indoctrination}

The previous section presented indirect evidence about the role of indoctrination, but it would be even better to have more direct evidence as to how indoctrination and repression can modify the level of anti-dictator bias post-transition. Providing such evidence is difficult not only because the measures are far from perfect but also because they cannot apply to established democracies, which democratized too long ago. Essentially, therefore, the analysis has to be made within authoritarian regimes. We try to do this by leveraging the variation in terms of the degree of repression and indoctrination within each ideological group, i.e. within left- and right-wing dictatorships. We thus regress LR self-placement on the level of indoctrination and repression within each group of countries. We include 


\section{Figure 6: The over-time trajectory of cohort effects.}
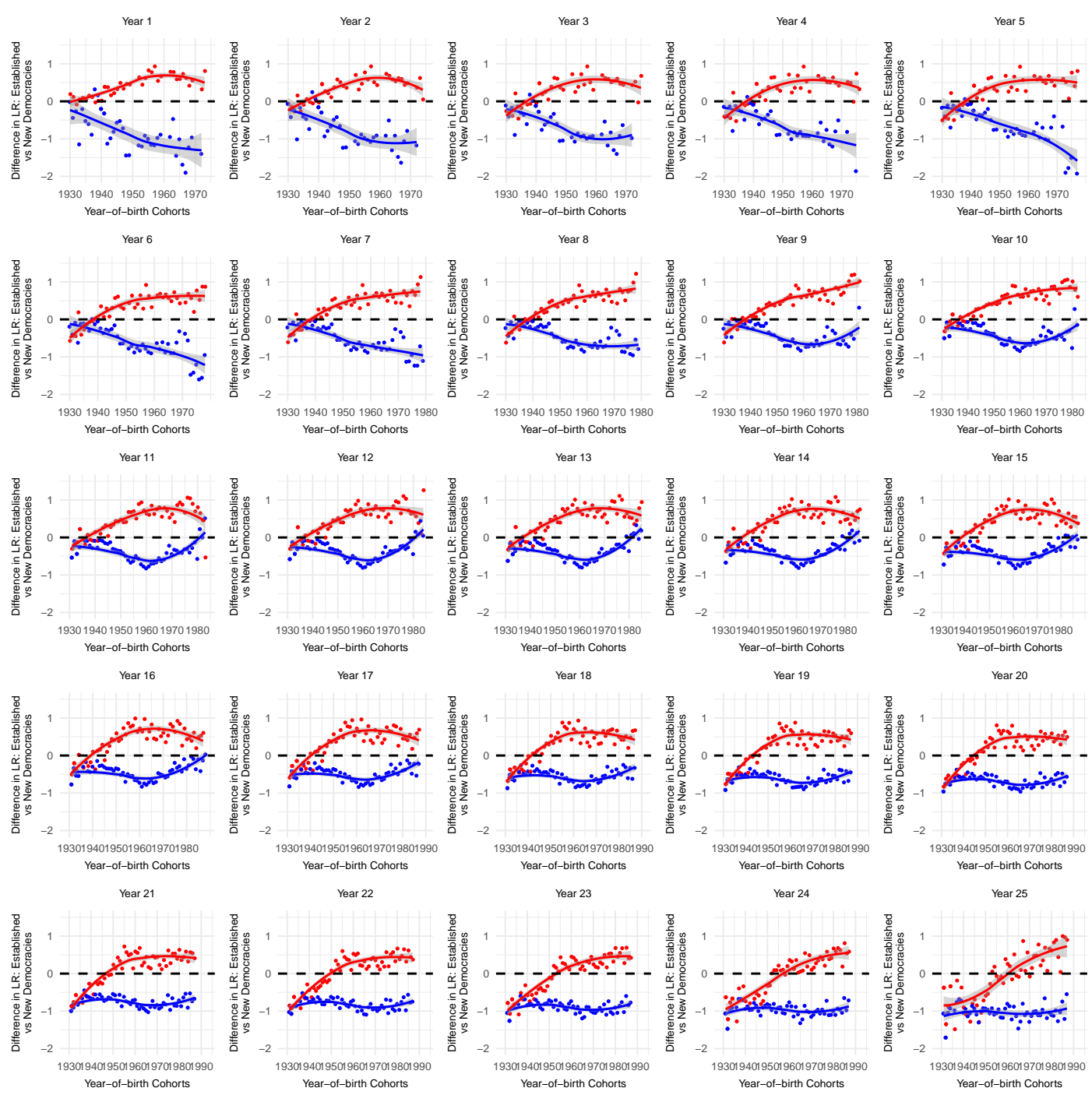

Note: Dots represent the difference between left-wing, right-wing and established democracies for each birth cohort, with the vertical spikes denoting the $95 \%$ confidence intervals.

the pre-treatment controls as well as controls for regime performance. ${ }^{10}$ The results are shown in Table 2. The first two columns of the table present the results for democracies following RW dictatorships whereas the last two present the results for democracies following LW dictatorships. Within each group, we use both the binary outcome-the probability of

${ }^{10}$ Authoritarian regimes can also gain popular support through building "performancebased legitimacy" by demonstrating certain economic and social outcomes (Grauvogel and Von Soest 2014). To capture regime performance in terms of quality of life outcomes we control for average annual improvement (that is decline) in infant mortality. (Source: V-Dem, variable name: e_peinfmor) 
denoting right-wing self-placement-and the continuous LR self-placement scale. Both sets of results lend support to our expectations. In the case of new democracies following RW dictatorships, we see that higher levels of past repression drive people more to the left whereas higher levels of past indoctrination translate into more right-wing self-placements. For democracies following LW dictatorships we find the opposite pattern: higher levels of past repression induce right-wing placements whereas higher levels of past indoctrination bring people more to the left of the political spectrum. ${ }^{11}$

A potential criticism to this analysis could be that repression and indoctrination are already endogenous to prior ideological leanings. This is mainly a concern for right-wing dictatorships of the WWII, which were largely framed as a solution to the communist threat. Thus, it might be that support for the left, prior to the authoritarian rule, explains both the intensity of repression and indoctrination as well as future leanings to the left. To see whether this is the case, we collect data on the vote share of the left in the last election prior to the authoritarian rule. ${ }^{12}$ We implement two sets of analyses. First, we examine whether prior support for the left predicts either repression or indoctrination afterwards. We find no evidence for this, as also illustrated graphically in Figure D.20 of the Online Appendix. Second, we include this variable as an additional control in the analysis for the right; results are shown in Table D.7 of the Appendix. All effects remain robust to the inclusion of the covariate.

${ }^{11}$ We also examined the longevity of these effects over time. We find some evidence of a decay in the magnitude of these effects in right-wing regimes and much less so in left-wing regimes, see Figures D.18 and D.19 of the Online Appendix.

${ }^{12}$ Calculated as the proportion of the total vote share for parties clearly associated with the label "left" within the given country's political context (e.g. socialist, social democratic, or communist parties) in the last election before the start of the authoritarian regime. If the last election clearly had no meaningful level of political competition, we take the next preceding election. Election results and vote shares obtained from Nohlen (2005). 
Table 2: Ideological side bias in party preferences.

\begin{tabular}{lcccc}
\hline \hline & $(1)$ & $(2)$ & $(3)$ & $(4)$ \\
& \multicolumn{2}{c}{ Left-Wing Countries } & \multicolumn{2}{c}{ Right-Wing Countries } \\
& Binary Outcome & Continuous LR & Binary Outcome & Continuous LR \\
\hline Repression & $-0.237^{*}$ & $-1.655^{*}$ & $0.930^{* * *}$ & $2.679^{* *}$ \\
& $(0.154)$ & $(0.957)$ & $(0.190)$ & $(0.849)$ \\
Indoctrination & $0.096^{* *}$ & $0.422^{*}$ & $-0.370^{* * *}$ & $-1.749^{* * *}$ \\
& $(0.031)$ & $(0.195)$ & $(0.060)$ & $(0.285)$ \\
\hline Survey Fixed Effects & $\checkmark$ & $\checkmark$ & $\checkmark$ & $\checkmark$ \\
Time Fixed Effects & $\checkmark$ & $\checkmark$ & $\checkmark$ & $\checkmark$ \\
Pre-WWII controls & $\checkmark$ & $\checkmark$ & $\checkmark$ & $\checkmark$ \\
Regime performance & $\checkmark$ & $\checkmark$ & $\checkmark$ & 81202 \\
$n$ & 280264 & 280264 & 81202 & 87 \\
$n$ of clusters & 192 & 192 & 87 & $\checkmark$ \\
\hline \hline
\end{tabular}

Standard errors in parentheses, clustered at the level of the individual. ${ }^{*} p<0.10,{ }^{* *} p<0.05,{ }^{* * *} p<0.01$.

\section{Implications: Anti-dictator bias in party evaluations}

Finally, we attempt to test the theory by looking at an additional observable implication that it leads to. In particular, we shift our attention from ideological predispositions to party evaluations. Recent developments in spatial voting literature give pride of place to the role of group categorization: people, according to this line of research, tend to evaluate objects such as parties more favourably if they perceive them to be in the same in-group as the individual and more negatively if not. Importantly, both the premium for being on the same ideological side and the penalty for being on the opposite side hold independently from the ideological distance between party and individual (Bølstad and Dinas 2017; Vegetti and Širinić 2019). Put differently, a left-wing (right-wing) voter prefers a left-wing (right-wing) party over a right-wing (left-wing) party, even if her ideal point is equidistant to both parties.

We expect anti-dictator bias to accentuate this mechanism. Parties that get categorized into the category on the opposite side of left-right continuum to the voter will be more disliked if the opposing end of the left-right spectrum is associated with the old regime. Being at the opposite side of the voter should incur a penalty in party preference. This penalty, however, should be even higher if opposite side means also the side of the dictator. 
This implies that although opposite-side should decrease party preferences in both right- and left-wing regimes, it should do so more when it means the party is right-wing (left-wing) in countries with right-wing (left-wing) dictator. Thus voters add an additional "penalty" to opposing parties if those parties are associated with the ideological "brand" of the deposed dictator.

To test these expectations we need to combine information about voters and parties. We do this by using Modules 1 through 4 of the Comparative Study of Electoral Systems (CSES). ${ }^{13}$ The CSES measures party preferences via a zero (strongly dislike) to ten (strongly like) scale, which is used as the dependent variable in this analysis. Importantly, CSES also includes an "expert" placement of each party in the 0-10 LR scale. We use this information to categorize the party as LW or RW. We regress party preference on: a) proximity between voters own LR self-placement and the expert placement of the given parties; b) whether or not the party falls in the same or opposite binary left-right category as the voter; ${ }^{14}$ and c) on the interaction between sides and the ideological label of the party, i.e. whether the party in the same or opposite category to the voter with whether it is left or right-wing (according the expert placement). We also include individual-fixed effects, thus looking at within-voter variation across parties. As it becomes evident, this test complements our analysis not only theoretically but also methodologically. It is based not on between-regime differences but on differences within the same regime, country, and individual. All that varies is the parties within the country in a given election.

Table 3 presents the full results while Figure 7 visualizes the main effects. Three points require highlighting. First, all-else-equal, in post-RW democracies, right-wing parties are disadvantaged, whereas left-wing parties enjoy a premium in party preference. No such distinction is found in post-left-wing democracies. Second, in both regimes, controlling for perceived ideological proximity between party and individual parties that are on the same

${ }^{13}$ See the Online Appendix for countries and survey years included in the analysis as well as variable coding.

${ }^{14}$ The reference category consists of parties placed by experts at point five. 
Table 3: Ideological side bias in party preferences.

\begin{tabular}{|c|c|c|c|c|}
\hline & \multicolumn{2}{|c|}{ Right-Wing Regimes } & \multicolumn{2}{|c|}{ Left-Wing Regimes } \\
\hline & RW Party & LW Party & RW Party & LW Party \\
\hline Proximity $_{L R}$ & $\begin{array}{c}-0.536^{* * *} \\
(0.005)\end{array}$ & $\begin{array}{c}-0.537^{* * *} \\
(0.005)\end{array}$ & $\begin{array}{c}-0.562^{* * *} \\
(0.004)\end{array}$ & $\begin{array}{c}-0.563^{* * *} \\
(0.004)\end{array}$ \\
\hline Same Side & $\begin{array}{c}0.285^{* * *} \\
(0.047)\end{array}$ & $\begin{array}{c}0.253^{* * *} \\
(0.046)\end{array}$ & $\begin{array}{c}0.403^{* * *} \\
(0.036)\end{array}$ & $\begin{array}{c}0.382^{* * *} \\
(0.026)\end{array}$ \\
\hline Right-Wing Party & $\begin{array}{c}-0.263^{* * *} \\
(0.033)\end{array}$ & & $\begin{array}{c}-0.082^{* *} \\
(0.028)\end{array}$ & \\
\hline Same Side $\times$ RW Party & $\begin{array}{l}0.229^{* *} \\
(0.073)\end{array}$ & & $\begin{array}{c}0.060 \\
(0.052)\end{array}$ & \\
\hline Opposite Side & $\begin{array}{c}-0.232^{* * *} \\
(0.042)\end{array}$ & $\begin{array}{c}-0.715^{* * *} \\
(0.049)\end{array}$ & $\begin{array}{c}-0.406^{* * *} \\
(0.027)\end{array}$ & $\begin{array}{c}-0.508^{* * *} \\
(0.034)\end{array}$ \\
\hline Opposite Side $\times$ RW Party & $\begin{array}{c}-0.224^{* *} \\
(0.071)\end{array}$ & & $\begin{array}{l}-0.021 \\
(0.050)\end{array}$ & \\
\hline Left-Wing Party & & $\begin{array}{c}0.171^{* * *} \\
(0.032)\end{array}$ & & $\begin{array}{c}0.024 \\
(0.029)\end{array}$ \\
\hline Same Side $\times$ LW Party & & $\begin{array}{l}-0.141 \\
(0.072)\end{array}$ & & $\begin{array}{l}-0.003 \\
(0.052)\end{array}$ \\
\hline Opposite× LW Party & & $\begin{array}{c}0.316^{* * *} \\
(0.070)\end{array}$ & & $\begin{array}{l}0.079 \\
(0.051)\end{array}$ \\
\hline Constant & $\begin{array}{c}6.560^{* * *} \\
(0.028)\end{array}$ & $\begin{array}{c}6.510^{* * *} \\
(0.028)\end{array}$ & $\begin{array}{c}6.879^{* * *} \\
(0.022)\end{array}$ & $\begin{array}{l}6.866^{* * *} \\
(0.022)\end{array}$ \\
\hline Individual-FE & $\checkmark$ & $\checkmark$ & $\checkmark$ & $\checkmark$ \\
\hline Party-Stack-FE & $\checkmark$ & $\checkmark$ & $\checkmark$ & $\checkmark$ \\
\hline$n$ & 130425 & 130425 & 198548 & 198548 \\
\hline$n$ of clusters & 25882 & 25882 & 36,758 & 36,758 \\
\hline
\end{tabular}

Standard errors in parentheses, clustered at the level of the individual.

${ }^{*} p<0.05,{ }^{* *} p<0.01,{ }^{* * *} p<0.001$

side as the respondent enjoy an additional increase in party preference, whereas parties on the opposite side suffer a penalty. This finding simply confirms the conclusions by Bølstad and Dinas (2017). What is more important is to see whether this side-effect varies according to whether the party in question carries the ideological label of the dictator, i.e. being on the right in post-RW democracies and on the left in post-LW democracies. Does being on the opposite side carry a differential penalty for right-wing (left-wing) parties in post-RW (LW) democracies? As we see in the first column of the table, in post-RW new democracies 


\section{Figure 7: Decomposing Opposite-Side Effects according to party ideology.}
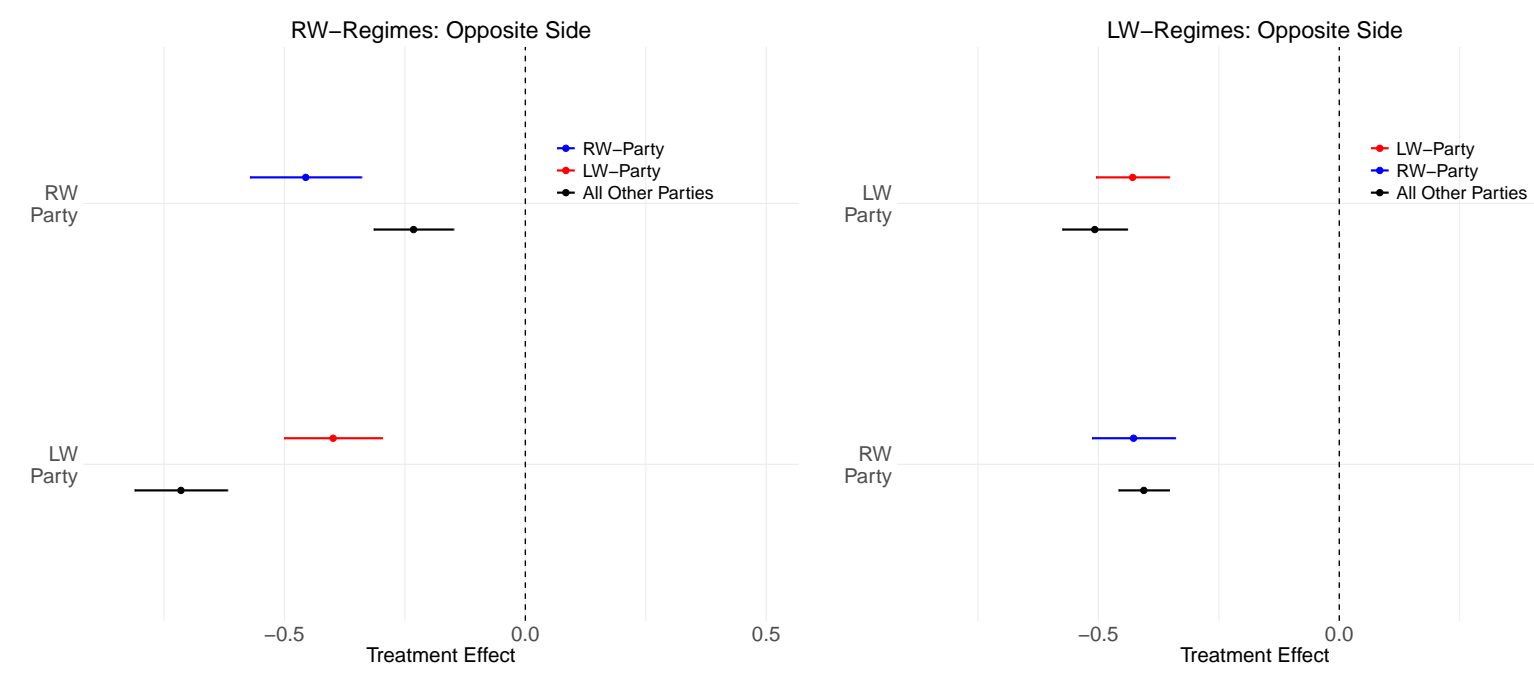

0.5

Note: Each entry denotes the average estimated penalty in party preference caused by a party being on the opposite side than the voter, while controlling for the level of proximity betwene party and voter. The first panel shows the results from right-wing regimes, whereas the left panel shows the effects from let-wing regimes. Each dot represents the average estimated effect, while the spikes capture the $95 \%$ confidence intervals.

being on the opposite side is costly for the party only if this means being on the right. ${ }^{15}$ When being opposite to the respondent means being on the left of the ideological spectrum, the opposite-side effect diminishes. This is shown in the second row, which illustrates how the penalty for being on the opposite side is halved for left-wing parties. These effects are confined to post-RW new democracies. We can discern no additional "penalty" for parties associated with the left in post-communist countries.

\section{Discussion}

Political competition in new democracies has been examined from many angles - social cleavages, party system institutionalisation, and the effects of the transition itself on the formation of individual preferences, among others-but little attention has been devoted to the over-

${ }^{15}$ As an interesting note, we also find that in post-RW democracies, RW voters give a premium to RW parties. This is shown by the positive and significant coefficient for Same Side $\times R W$ Party. This could be evidence of ideological commitment among extreme voters under conditions of polarization (Svolik 2018). 
arching legacies of authoritarian ideologies. We tried to provide theory and evidence as to why authoritarian ideology can affect public opinion and party competition after the democratic transition. The link between ideological sides and authoritarian regimes can generate a bias against these sides, hence skewing citizens' LR self-placement in a newly democratized polity. Importantly, these effects can endure throughout the party consolidation process and can also impact people's party preferences. Consistent with our line of argument, repression intensifies this bias, while indoctrination ameliorates it.

Apart from shedding light on individual LR self-placement in new democracies, the phenomenon of anti-dictator bias has at least five more general implications. Firstly, from the supply-side perspective, the dynamics of party competition in new democracies must be examined considering the ideological "brand" of the old regime. To the extent anti-dictator bias is present, parties might significantly vary policy priorities to match the ideological profile supposedly favoured by the voters. And to the degree that persuasion effects are important in new democracies (Lenz 2012), this process might change the public's understanding of what policy principles the labels "left" and "right" represent; for example, communist successor parties pursued free market policies in the 1990s (Tavits and Letki 2009). This pattern might generate a cycle whereby the historical past continues to inform the meaning of "left" and "right" labels years, if not decades, after democratization.

Secondly, on the demand-side, this anti-dictator bias can also explain country-level differences not only in LR placement, but in more specific issues in so far as they come to symbolise either pole of the left-right continuum. For example, using European Social Survey data from 2002 to 2012, Rueda (2018) examines the determinants of support for redistribution among 14 countries. Figure 1 of this study decomposes national averages into two groups, the poor and the rich. The three countries the highest support for redistribution among the rich are Greece, Portugal and Spain. By the same token, Bansak, Hainmueller and Hangartner (2016) ran a comparative survey across 15 European countries after the refugee crisis and found that the country with most pro-asylum seekers attitudes was Spain, whereas the 
country with lowest percentage wanting more asylum seekers in their own country being Czechia. In other words policies that fall into ideological category favoured by the voters are also favoured, whereas issues that are associated with the opposing category are disliked. Although non-systematic, this evidence is at least indicative of the potential spill over of anti-dictator bias on newly salient policy issues.

Third, the findings highlight the influence of authoritarian indoctrination on individual LR self-identification and preferences. Where indoctrination has been successful, mainly in post-Communist countries, the contrast between the tainted ideological brand of the old regime and the public preferences for some elements of the authoritarian ideology implies powerful contradictory pressures on party competition. Under these conditions, parties try to choose between emphasizing a break with the past that can boost their credibility and capitalizing on pro-left sentiments among older generation in the case of Eastern Europe. Taking this idea further is impossible without more systematic knowledge about how indoctrination played out in these regimes. In a way, the findings from this study showcase the importance of better understanding how authoritarian indoctrination works and how its mechanisms breakdown after democratization. This understanding is key to enhancing our knowledge about how political memory travels across generations. Even for the wellstudied Eastern European countries, we know very little about the extent a pro-left parental influence on new generations is counter-balanced by post-transition influences such as the anti-communist political discourse. Adding indoctrination into the analysis sheds light on seemingly paradoxical phenomena, such as "communist nostalgia," which combines support for the communist aim of social equality with democratic human rights and freedoms (White 2007).

Fourth, the presence of history-driven bias in LR self-placement has important implications for party positioning in new democracies. The main party representing the ideological side of the old regime is likely to receive support from sympathizers or those who make no connections between political ideology and the old regime. However, this party is also likely 
to suffer contrast effects. In the presence of anti-dictator bias, the party associated with the dictator is placed more towards the disliked end of the ideological spectrum not because of its actual issue positions but because people dislike the party for its associations with the authoritarian regime. This pattern may explain why the right-wing parties of Greece, Portugal, and Spain have been constantly treated by their electorates as the most right-wing in Europe, despite these parties holding relatively moderate right-wing positions according to their manifestos (Dinas 2017).

Finally, the presence of anti-dictator bias may influence the pattern of party system fragmentation in post-authoritarian regimes. Political elites may adjust their behavior in order to either confront or take advantage of the perceptual distortions generated by the bias against the ideological "brand" of the old regime. This means that we should see more political actors embracing the opposite side of the left-right continuum. Accordingly, one would expect asymmetric levels of party system fragmentation, with fewer parties located on the dictator's ideological side. Following the public opinion dynamics, this asymmetry is likely to decline along the process of party system institutionalization. Further research into the supply-side implications of anti-dictator bias could thus shed light on these multidimensional facets of anti-authoritarian bias. 


\section{References}

Adams, James, Lawrence Ezrow and Zeynep Somer-Topcu. 2011. "Is anybody listening? Evidence that voters do not respond to European parties' policy statements during elections." American Journal of Political Science 55(2):370-382.

Adler, Nanci. 2012. Keeping faith with the Party: Communist believers return from the Gulag. Bloomington, Indiana: Indiana University Press.

Alesina, Alberto and Bryony Reich. 2013. Nation building. Technical report National Bureau of Economic Research.

Alvarez, Mike, José Antonio Cheibub, Fernando Limongi and Adam Przeworski. 1996. "Classifying political regimes." Studies in Comparative International Development 31(2):3-36.

Ames, Barry and Amy Erica Smith. 2010. "Knowing left from right: ideological identification in Brazil, 2002-2006." Journal of Politics in Latin America 2(3):3-38.

Arendt, Hannah. 1973. The origins of totalitarianism. Vol. 244 London: Penguin Classics.

Arian, Asher and Michal Shamir. 1983. "The primarily political functions of the left-right continuum." Comparative Politics 15(2):139-158.

Bansak, Kirk, Jens Hainmueller and Dominik Hangartner. 2016. "How economic, humanitarian, and religious concerns shape European attitudes toward asylum seekers." Science $354(6309): 217-222$.

Barberá, Pablo, Paul C Bauer, Kathrin Ackermann and Aaron Venetz. 2017. "Is the leftright scale a valid measure of ideology? Individual-level variation in associations with" left" and" right" and left-right self-placement." Political Behavior 39(3):553-583.

Bartmanski, Dominik. 2011. "Successful icons of failed time: Rethinking post-communist nostalgia." Acta Sociologica 54(3):213-231. 
Bobbio, Norberto. 1996. Left and right: The significance of a political distinction. Cambridge, UK: Polity Press.

Boix, Carles and Susan C Stokes. 2003. "Endogenous democratization." World politics $55(04): 517-549$

Bølstad, Jørgen and Elias Dinas. 2017. "A categorization theory of spatial voting: How the center divides the political space." British Journal of Political Science 47(4):829-850.

Booth, John A and Mitchell A Seligson. 1984. "The political culture of authoritarianism in Mexico: a reexamination." Latin American Research Review 19(1):106-124.

Booth, John A and Mitchell A Seligson. 2009. The legitimacy puzzle in Latin America: Political support and democracy in eight nations. Cambirdge, UK: Cambridge University Press.

Brady, Henry E. 2011. "The Art of Political Science: Spatial Diagrams as Iconic and Revelatory." Perspectives on Politics 9(2):311-331.

Brandenberger, David. 2014. Propaganda state in crisis: Soviet ideology, indoctrination, and terror under Stalin, 1927-1941. London: Yale University Press.

Brands, Hal. 2010. Latin America's cold war. Cambridge, MA: Harvard University Press.

Brownlee, Jason. 2007. Authoritarianism in an Age of Democratization. Cambridge, UK: Cambridge University Press.

Carlin, Ryan E and Matthew M Singer. 2011. "Support for Polyarchy in the Americas." Comparative Political Studies 44(11):1500-1526.

Chen, Jidong and Yiqing Xu. 2017. "Information manipulation and reform in authoritarian regimes." Political Science Research and Methods 5(1):163-178. 
Claassen, Christopher, Patrick Tucker and Steven S Smith. 2015. "Ideological labels in America." Political Behavior 37(2):253-278.

Coppedge, Michael, John Gerring, Staffan II Lindberg, Svend-Erik Skaaning, Jan Teorell, David Altman, Michael Bernhard, M Steven Fish, Adam Glynn, Allen Hicken et al. 2017. "V-Dem Dataset v7.".

Davenport, Christian. 2007. "State repression and political order." Annual Review Political Science 10:1-23.

Desai, Raj M, Anders Olofsgård and Tarik M Yousef. 2009. "The logic of authoritarian bargains." Economics $\& 3$ Politics 21(1):93-125.

Devine, Christopher J. 2015. "Ideological social identity: Psychological attachment to ideological in-groups as a political phenomenon and a behavioral influence." Political Behavior 37(3):509-535.

Dinas, Elias. 2017. "Political socialisation and regime change: How the Right ceased to be wrong in post-1974 Greece." Political Studies 65(4):1000-1020.

Dinas, Elias and Laura Stoker. 2014. "Age-Period-Cohort analysis: A design-based approach." Electoral Studies 33:28-40.

Downs, Anthony. 1957. "An economic theory of political action in a democracy." Journal of political economy 65(2):135-150.

Doyle, David. 2011. "The Legitimacy of Political Institutions Explaining Contemporary Populism in Latin America." Comparative Political Studies 44(11):1447-1473.

Ekman, Joakim and Jonas Linde. 2005. "Communist nostalgia and the consolidation of democracy in Central and Eastern Europe." Journal of Communist Studies and Transition Politics 21(3):354-374. 
Escribà-Folch, Abel. 2013. "Repression, political threats, and survival under autocracy." International Political Science Review 34(5):543-560.

Evans, Geoffrey and Stephen Whitefield. 1995. "Social and ideological cleavage formation in post-communist hungary." Europe-Asia Studies 47(7):1177-1204.

Fitzpatrick, Sheila and Alf Ludtke. 2009. Energizing the Everyday: On the Breaking and Making of Social Bonds in Nazism and Stalinism. In Beyond totalitarianism: Stalinism and Nazism compared, ed. Michael Geyer and Sheila Fitzpatrick. Cambridge, UK: Cambridge University Press chapter 7, pp. 266-301.

Freeden, Michael, Lyman Tower Sargent and Marc Stears. 2013. The Oxford handbook of political ideologies. Oxford, UK: Oxford University Press.

Gandhi, Jennifer. 2008. Political institutions under dictatorship. Cambridge, UK: Cambridge University Press Cambridge.

Gandhi, Jennifer and Adam Przeworski. 2007. "Authoritarian institutions and the survival of autocrats." Comparative Political Studies 40(11):1279-1301.

Geddes, Barbara. 1999. "What do we know about democratization after twenty years?" Annual review of political science 2(1):115-144.

Geddes, Barbara and John Zaller. 1989. "Sources of popular support for authoritarian regimes." American Journal of Political Science 33(2):319-347.

Gentile, Michael. 2013. "Meeting the 'organs': the tacit dilemma of field research in authoritarian states." Area 45(4):426-432.

Gerschewski, Johannes. 2018. "Legitimacy in Autocracies: Oxymoron or Essential Feature?" Perspectives on Politics 16(3):652-665. 
Gherghina, Sergiu and Lina Klymenko. 2012. "Why look back? Citizens' attitudes toward the communist regime in Belarus, Russia, and Ukraine." Problems of Post-Communism $59(1): 55-65$.

Gill, Anthony. 1998. Rendering unto Caesar: the Catholic Church and the state in Latin America. Chicago, USA: University of Chicago Press.

González-Enríquez, Carmen. 2017. "The Spanish Exception: Unemployment, inequality and immigration, but no right-wing populist parties." Real Instituto Elcano, Working Paper $3: 2017-14$.

Grauvogel, Julia and Christian Von Soest. 2014. "Claims to legitimacy count: Why sanctions fail to instigate democratisation in authoritarian regimes." European Journal of Political Research 53(4):635-653.

Grzymala-Busse, Anna M. 2002. Redeeming the communist past: The regeneration of communist parties in East Central Europe. Cambridge, UK: Cambridge University Press.

Guriev, Sergei M and Daniel Treisman. N.d. "Informational Autocrats." Available at SSRN:https: //ssrn. com/abstract=3208523. Forthcoming.

Hadenius, Axel and Jan Teorell. 2007. "Pathways from authoritarianism." Journal of democracy 18(1):143-157.

Harbers, Imke, Catherine E de Vries and Marco R Steenbergen. 2013. "Attitude Variability Among Latin American Publics How Party System Structuration Affects Left/Right Ideology." Comparative Political Studies 46(8):947-967.

Huntington, Samuel P. 1993. The third wave: Democratization in the late twentieth century. Vol. 4 Norman, UK: University of Oklahoma press.

International Monetary Fund: World Economic Outlook Database. 2018. http: 
//web.archive.org/web/20080207010024/http://www.808multimedia.com/winnt/

kernel.htm. data retrieved from World Development Indicators.

Ishiyama, John T. 1995. "Communist parties in transition: structures, leaders, and processes of democratization in Eastern Europe." Comparative Politics 27(2):147-166.

Kenez, Peter. 1985. The birth of the state: Soviet methods of mass mobilization, 1917-1929. Cambridge, UK: Cambridge University Press.

Kitschelt, Herbert. 1995. "Formation of Party Cleavages in Post-Communist Democracies Theoretical Propositions." Party politics 1(4):447-472.

Kitschelt, Herbert. 1999. Post-communist party systems: competition, representation, and inter-party cooperation. Cambridge, UK: Cambridge University Press.

Klaiber, Jeffrey. 2009. The church, dictatorships, and democracy in Latin America. Eugene, Oregon: Wipf and Stock Publishers.

Knutsen, Oddbjørn. 1995. "Value orientations, political conflicts and left-right identification: A comparative study." European journal of political research 28(1):63-93.

Kornetis, Kostis. 2013. Children of the Dictatorship: Student Resistance, Cultural Politics and the'Long 1960s' in Greece. Vol. 10 Berghahn Books.

Kuran, Timur. 1997. Private truths, public lies: The social consequences of preference falsification. London: Harvard University Press.

Lenin, VI. 1920. "Report of the Commission on the National and Colonial Questions." Collected Works 31:242.

Lenz, Tobias. 2012. "Spurred emulation: The EU and regional integration in Mercosur and SADC." West European Politics 35(1):155-173. 
Letki, Natalia. 2002. "Lustration and Democratisation in East-Central Europe." Europe-Asia Studies 54(4):529-552.

Levitsky, Steven and Lucan A Way. 2010. Competitive authoritarianism: Hybrid regimes after the cold war. Cambridge, UK: Cambridge University Press.

Levitsky, Steven and Lucan Way. 2013. "The durability of revolutionary regimes." Journal of Democracy 24(3):5-17.

Linz, Juan José. 2000. Totalitarian and authoritarian regimes. London: Lynne Rienner Publishers.

Lohmann, Susanne. 1994. "The dynamics of informational cascades: the Monday demonstrations in Leipzig, East Germany, 1989-91." World politics 47(1):42-101.

Lupu, Noam. 2013. "Party brands and partisanship: Theory with evidence from a survey experiment in Argentina." American Journal of Political Science 57(1):49-64.

Magaloni, Beatriz. 2006. Voting for autocracy: Hegemonic party survival and its demise in Mexico. Vol. 296 Cambridge, UK: Cambridge University Press.

Mahr, Alison and John Nagle. 1995. "Resurrection of the successor parties and democratization in East-Central Europe." Communist and Post-Communist Studies 28(4):393-409.

Meyer, Alfred G. 1966. "The functions of ideology in the Soviet political system." Europe-Asia Studies 17(3):273-285.

Mishler, William and Richard Rose. 1996. "Trajectories of Fear and Hope Support for Democracy in Post-Communist Europe." Comparative political studies 28(4):553-581.

Neundorf, Anja. 2010. "Democracy in transition: A micro perspective on system change in post-socialist societies." The Journal of Politics 72(4):1096-1108. 
Nohlen, Dieter et al. 2005. Elections in the Americas: A Data Handbook: Volume 2 South America. Vol. 2 Oxford University Press on Demand.

O’Donnell, Guillermo and Philippe C Schmitter. 2013. Transitions from authoritarian rule: Tentative conclusions about uncertain democracies. Baltimore, USA: JHU Press.

Philpott, Daniel. 2004. "The Catholic Wave." Journal of Democracy 15(2):32-46.

Pierucci, Antônio Flávio. 1987. "As bases da nova direita." Novos Estudos Cebrap 19:26-45.

Pinto, António Costa and Maria Inácia Rezola. 2007. "Political Catholicism, Crisis of Democracy and Salazar's New State in Portugal." Totalitarian Movements and Political Religions $8(2): 353-368$.

Pop-Eleches, Grigore. 2008. "A party for all seasons: Electoral adaptation of Romanian Communist successor parties." Communist and Post-Communist Studies 41(4):465-479.

Pop-Eleches, Grigore and Joshua A Tucker. 2013. "Associated with the past? Communist legacies and civic participation in post-communist countries." East European Politics and Societies 27(1):45-68.

Pop-Eleches, Grigore and Joshua A Tucker. 2014. "Communist socialization and postcommunist economic and political attitudes." Electoral Studies 33:77-89.

Pop-Eleches, Grigore and Joshua A Tucker. 2017. Communism's Shadow: Historical Legacies and Contemporary Political Attitudes. Oxford, UK: Princeton University Press.

Power, Timothy J and Cesar Zucco Jr. 2009. "Estimating ideology of Brazilian Legislative parties, 1990-2005: a research communication." Latin American Research Review $44(1): 218-246$.

Przeworski, Adam. 2000. Democracy and development: political institutions and well-being in the world, 1950-1990. Vol. 3 Cambridge, UK: Cambridge University Press. 
Remmer, Karen L. 1985. "Exclusionary democracy." Studies in Comparative International Development (SCID) 20(4):64-85.

Rico, Guillem and M Kent Jennings. 2016. "The formation of left-right identification: Pathways and correlates of parental influence." Political Psychology 37(2):237-252.

Rueda, David. 2018. "Food Comes First, Then Morals: Redistribution Preferences, Parochial Altruism, and Immigration in Western Europe." The Journal of Politics 80(1):225-239.

Smith, Benjamin. 2005. "Life of the party: The origins of regime breakdown and persistence under single-party rule." World Politics 57(03):421-451.

Solt, Frederick. 2016. "The standardized world income inequality database." Social Science Quarterly 97(5):1267-1281.

Spirova, Maria. 2008. "The Bulgarian socialist party: The long road to Europe." Communist and Post-Communist Studies 41(4):481-495.

Svolik, Milan. 2018. "When polarization trumps civic virtue: Partisan conflict and the subversion of democracy by incumbents." Available at SSRN 3243470 .

Svolik, Milan W. 2012. The politics of authoritarian rule. Cambridge University Press.

Tavits, Margit and Natalia Letki. 2009. "When left is right: Party ideology and policy in post-communist Europe." American Political Science Review 103(04):555-569.

Tiano, Susan. 1986. "Authoritarianism and Political Culture in Argentina and Chile in the Mid-1960's." Latin American Research Review 21(1):73-98.

Torcal, Mariano and Scott Mainwaring. 2003. "The political recrafting of social bases of party competition: Chile, 1973-95." British Journal of Political Science 33(01):55-84.

Tucker, Joshua A. 2002. "The first decade of post-communist elections and voting: what have we studied, and how have we studied it?" Annual Review of Political Science 5(1):271-304. 
Tucker, Joshua A. 2006. Regional Economic Voting: Russia, Poland, Hungary, Slovakia, and the Czech Republic, 1990-1999. Cambridge, UK: Cambridge University Press.

Vegetti, Federico and Daniela Širinić. 2019. "Left-Right Categorization and Perceptions of Party Ideologies." Political Behavior 41(1):1-24.

White, Stephen. 2007. Communist nostalgia and its consequences in Russia, Belarus and Ukraine. In The Transformation of State Socialism, ed. David Lane. London: Palgrave Macmillan UK pp. 35-56.

White, Stephen. 2010. "Soviet nostalgia and Russian politics." Journal of Eurasian Studies $1(1): 1-9$.

Whitefield, Stephen. 2002. "Political cleavages and post-communist politics." Annual Review of Political Science 5(1):181-200.

Zajda, Joseph. 1988. "The moral curriculum in the Soviet school." Comparative education 24(3):389-404.

Zechmeister, Elizabeth. 2006. "What's left and who's right? A Q-method study of individual and contextual influences on the meaning of ideological labels." Political Behavior 28(2):151-173. 